\title{
Direct Cadmium Monitoring in Cigarette Filters Leachate by Molecular Fluorescence
}

\author{
María Carolina Talio ${ }^{1}$, Tristán A. Bonfiglioli ${ }^{2}$, Marta O. Luconi ${ }^{2}$, Liliana P. Fernández ${ }^{1,2^{*}}$ \\ ${ }^{1}$ Instituto de Química de San Luis (INQUISAL-CONICET), Chacabuco y Pedernera, San Luis, Argentina; ${ }^{2}$ Área de Química \\ Analítica, Facultad de Química, Bioquímica y Farmacia, Universidad Nacional de San Luis, San Luis, Argentina. \\ Email: "1fernand@unsl.edu.ar
}

Received November $17^{\text {th }}, 2011$; revised December $15^{\text {th }}, 2011$; accepted January $17^{\text {th }}, 2012$

\begin{abstract}
This work proposes a new direct flourimetric methodology for cadmium traces quantification based on its association with azo-reagent SPADNS and rhodamine B dye. Experimental variables that influence on fluorimetric sensibility were optimized using uni-variation assays. The calibration graph using zero ${ }^{\text {th }}$ order calibration was linear from 0.192 to 1.26 $10^{4} \mu \mathrm{g} \cdot \mathrm{L}^{-1}$, with a correlation coefficient of 0.99 . Under the optimal conditions, it was obtained a limit of detection of $0.057 \mu \mathrm{g} \cdot \mathrm{L}^{-1}$ and a limit of quantification of $0.192 \mu \mathrm{g} \cdot \mathrm{L}^{-1}$. The method showed good sensitivity, adequate selectivity with good tolerance to foreign ions, and was applied to the determination of trace amounts of cadmium in filters leachates coming from unsmoked, automatically smoked and smokers smoked cigarettes with satisfactory results. The proposed method represents an innovative application of luminescence to metal analysis comparable in sensitivity and accuracy to atomic spectroscopies.
\end{abstract}

Keywords: Cadmium Traces; SPADNS; Rhodamine B; Molecular Fluorescence; Cigarette Filters Leachate

\section{Introduction}

Tobacco smoke is an aerosol consisting of solid/liquid droplets (particulate phase) in a gaseous phase generated by the combustion of its components at high temperature [1]. More than 4000 compounds have been identified in environmental tobacco smoke $[2,3]$.

Cigarette filter was introduced in 1954, when doctors and researchers announced a possible link between lung diseases and smoking $[4,5]$. The presence of a "filter" on the end of a cigarette implied a theoretical reduction of harmful smoke constituents entering their smoker body, introducing the concept of "safe smoking".

Although the principal purpose of filters is to absorb some of the harmful chemicals of tobacco smoke, a filter has its own chemicals that affect smokers and the environment. Nowadays, butts or cigarette filters are the main source of waste in the world, discarding on average 4.5 trillion cigarette butts each year [6]. Due to they are made of acetate, a non-biodegradable material, they remain long time in the environment being a potential source of contamination. When smokers do not discard cigarette butts properly, the butts can end up in water systems, where they pollute the water by leaking out the toxically substances they were designed to retain and preconcentrate.

\footnotetext{
"Corresponding author.
}

Cadmium is a known carcinogen and is one of the components of tobacco [7]. It has been proved quantitatively that exposure to cigarette smoke is harmful to both active and passive smokers. It can cause alterations in the enzymatic, renal, respiratory and digestive systems, with a very long half-life. Smokers may absorb amounts comparable to normal daily intake in the diet, i.e. from 0.1 to $0.2 \mathrm{mg}$ inhaled cadmium per cigarette, with absorption of approximately $50 \%$.

Cadmium traces determination result a main topic in environmental, monitoring control processes and toxicological-clinical areas. They are frequently determined by atomic techniques such as atomic absorption spectrometry, inductively coupled plasma (ICP)-atomic emission spectrometry and ICP-mass spectrometry associated to a previous preconcentration step [8-11]. Particularly, cadmium determination in biological and environmental samples at ultra-trace levels, have been supported by ETAAS with in-atomizer trapping [12].

The application of molecular fluorescence in cadmium traces determination has put in evidence analytical advantages such as high sensitivity, proper selectivity and wide dynamic range when it is associate to separation/ preconcentration step [13,14].

Taking into account the development of simple, fast, sensitive and precise methodologies for cadmium traces determination results imperative, the aim of present work 
is to propose an alternative methodology to traditional atomic spectroscopies for cadmium monitoring in filter leachates, not including any separation/preconcentration step, using an instrument accessible in control laboratories. Fluorimetric determination of cadmium is based on the formation of a ternary association complex with SPADNS azo-reagent and rhodamine B, a methyl-xanthene dye (RhB).

\section{Experimental}

\subsection{Reagents}

Stock solutions of $\mathrm{Cd}$ (II) $1 \times 10^{-5} \mathrm{~mol} \cdot \mathrm{L}^{-1}$ were prepared by dilution of $100 \mu \mathrm{g} \cdot \mathrm{mL}^{-1}$ standard solution plasmapure (Leeman Labs, Inc.).

Buffer acetic/acetate (Mallinckrodt Chemical Works, New York, Los Angeles, St. Louis, USA) $1 \times 10^{-2} \mathrm{~mol} \cdot \mathrm{L}^{-1}$ solution was prepared. This solution was adjusted to the desired $\mathrm{pH}$, with aqueous $\mathrm{NaOH}$ (Mallinckrodt Chemical Works) using a pHmeter (Orion Expandable Ion Analyzer, Orion Research, Cambridge, MA, USA) Model EA 940.

Stock of RhB solution $1 \times 10^{-6} \mathrm{~mol} \cdot \mathrm{L}^{-1}$ (Fluka AG, Chemische Fabrik, Buchs SG, Switzerland) and SPADNS (trisodium salt of 2-(4-sulfophenylazo)-1,8-dihydroxy3,6-naphthalenedisulfonic, Merck, Darmstadt, Germany) $1 \times 10^{-6} \mathrm{~mol} \cdot \mathrm{L}^{-1}$ solution were weekly prepared by dissolution of the appropriate amount of each, in ultrapure water. The stability of solutions was checked by spectrophotometric measurements.

All used reagent were analytical grade.

\subsection{Apparatus}

Spectrofluorimetric measurements were made using a Shimadzu RF-5301 PC spectrofluorophotometer equipped with a $150 \mathrm{~W}$ Xenon lamp and $1.00 \mathrm{~cm}$ quartz cells.

\subsection{General Procedure}

An adequate aliquot of filter leachate solutions $(25 \mu \mathrm{L}$ $250 \mu \mathrm{L}$ ) coming from unsmoked, automatically smoked or smokers smoked cigarettes, Cd(II) aliquot $\left(0.19 \mu \mathrm{g} \cdot \mathrm{mL}^{-1}\right.$ - $\left.1.26 \times 10^{4} \mu \mathrm{g} \cdot \mathrm{mL}^{-1}\right), 100 \mu \mathrm{L}$ buffer acetic-acetate solution $1 \times 10^{-2} \mathrm{~mol} \mathrm{~L}^{-1}(\mathrm{pH}=5.8), 250 \mu \mathrm{L} \mathrm{RhB}\left(1 \times 10^{-6}\right.$ $\left.\mathrm{mol} \cdot \mathrm{L}^{-1}\right)$ and $100 \mu \mathrm{L} \mathrm{SPADNS}\left(1 \times 10^{-6} \mathrm{~mol} \cdot \mathrm{L}^{-1}\right)$ were placed in a $10 \mathrm{~mL}$ glass volumetric flask. The whole mixture was diluted to $10 \mathrm{~mL}$ with ultrapure water. Fluorescent emission was measured at $\lambda_{\mathrm{em}}=384 \mathrm{~nm}\left(\lambda_{\mathrm{exc}}=\right.$ $228 \mathrm{~nm})$.

\subsection{Sampling Procedure and Sample Treatment}

Smokers were advised respect to the correct filter collection. Then of smoking the cigarette and to put out it on a clean glass ashtray, each smoker collected his filters arising from a unique cigarette brand in a polyethylene recipe. In order to prevent environmental humidity, recipes were immediately closed with plastic cap. Next, samples were remitted to laboratory for their immediately examination.

For other side, cigarettes were automatically smoked by connection to a vacuum pump.

Filters of unsmoked cigarettes were also assayed; filters were extracted to cigarettes from recently opened packages.

Filters were carefully dismantled, wasting paper, ash and tobacco remains; then, they were immediately weighted. Afterward, each filter was put in leachate solution prepared with $1 \mathrm{~mL}$ of buffer acetic/acetate $1 \times 10^{-2} \mathrm{~mol} \cdot \mathrm{L}^{-1}$ $\mathrm{pH} 4$, and $9 \mathrm{~mL}$ of ultra pure water.

Each filter was separately leachated during 1 minute, with continuous manual shake. An adequate aliquot of each leachate solution was used to apply general procedure.

All used glass materials were previously washed with a $10 \% \mathrm{v} / \mathrm{v} \mathrm{HNO}_{3}$ solution and then with ultrapure water.

\section{Results and Discussion}

\subsection{Fluorescent Spectra}

The fluorescence of SPADNS-Cd(II) system was explored in aqueous medium without satisfactory results respect to sensitivity. Taken into account that previous studies have exposed the feasibility of formation of ternary complexes between metallic ions, SPADNS and RhB dyes [15], the effect of RhB addition on SPADNS-Cd(II) system was examined. The obtained results showed an important enhancement of the fluorescent signal for the ternary system; this fact supports the formation of a ternary association complex between Cd(II), SPADNS and $\mathrm{RhB}$, with an extra advantage respect to the sensibility of the luminescent response as can be seen in Figure 1.

\subsection{Optimization of Experimental Condition for Cd(II)-RhB-SPADNS System}

In order to find the optimum experimental conditions for Cd(II)-RhB-SPADNS association formation, experimental parameters such as $\mathrm{pH}$, nature and concentration of buffer solution, concentrations of chelating reagent, dye concentrations, solvent, that affecting the complexation reaction were consecutively investigated.

The first parameter examined was the $\mathrm{pH}$; this parameter plays a unique role on metal-chelate formation and the subsequent metal determination. The results illustrated in Figure 2, showed that at $\mathrm{pH}$ above 5.5, a maximum in fluorescence signal was obtained. Due to this behavior, the $\mathrm{pH}$ value of 5.8 was selected as working value for the following experiences. 


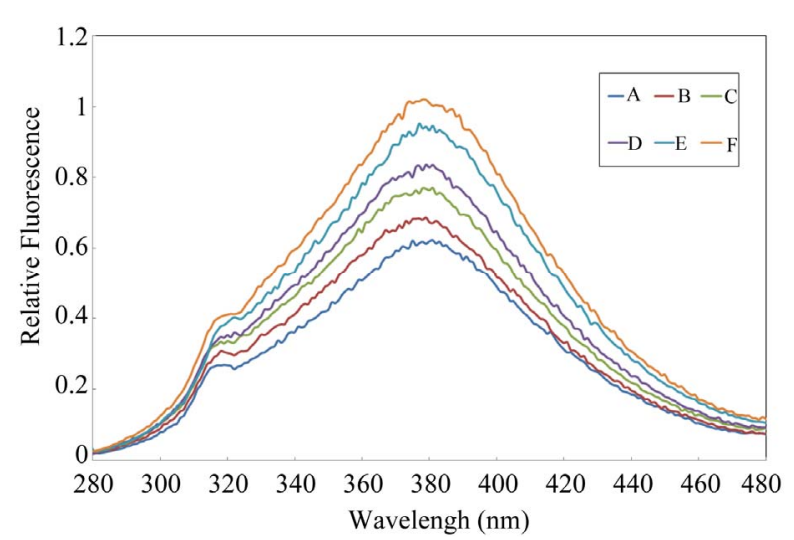

Figure 1. Fluorescent spectra of SPADNS-RhB and Cd(II)SPADNS-RhB systems. Conditions: $1 \times 10^{-8} \mathrm{~mol} \cdot \mathrm{L}^{-1} \mathrm{SPA}-$ DNS, $2.5 \times 10^{-8} \mathrm{~mol} \cdot \mathrm{L}^{-1} \mathrm{RhB}$, pH $5.8 \mathrm{buffer}$ acetic/acetate. Other experimental conditions are described under procedures. A: SPADNS-RhB system; B: Idem A + Cd(II) 1.26 $\mu \mathrm{g} \cdot \mathrm{L}^{-1}$; C: Idem A + Cd(II) $2.5 \mu \mathrm{g} \cdot \mathrm{L}^{-1}$; D: Idem A + Cd(II) $5.1 \mu \mathrm{g} \cdot \mathrm{L}^{-1}$; E: Idem A + Cd(II) $7.7 \mu \mathrm{g} \cdot \mathrm{L}^{-1} ; \mathrm{F}$ : idem A + Cd(II) $10.2 \mu \mathrm{g} \cdot \mathrm{L}^{-1}$.

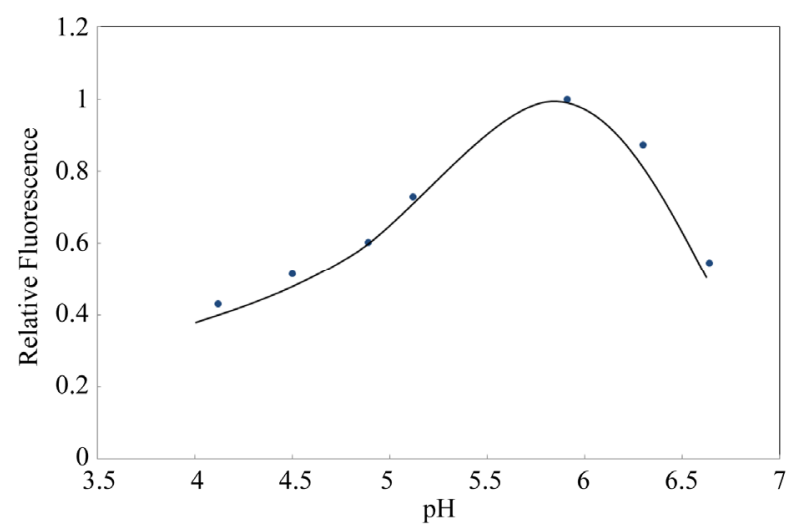

Figure 2. Influence of buffer acetic/acetate concentration on cadmium association complex with SPADNS and RhB. Conditions: $1.26 \mu \mathrm{g} \cdot \mathrm{L}^{-1} \mathrm{Cd}(\mathrm{II}), 1 \times 10^{-8} \mathrm{~mol} \cdot \mathrm{L}^{-1} \mathrm{SPADNS}$, $2.5 \times 10^{-8} \mathrm{~mol} \cdot \mathrm{L}^{-1} \mathrm{RhB}$. Other experimental conditions are described under procedures.

The effect of different buffers on the fluorescence signal of $\mathrm{Cd}(\mathrm{II})-\mathrm{RhB}-\mathrm{SPADNS}$ ternary system was tested. The most enhanced fluorescent emission was obtained using buffer acetic/acetate. The fluorescence response was studied within acetic/acetate concentration range from $4 \times 10^{-4}$ to $0.5 \mathrm{~mol} \cdot \mathrm{L}^{-1}$. The best performance and optimal stability was achieved for a buffer concentration $1.2 \times 10^{-4} \mathrm{~mol} \cdot \mathrm{L}^{-1}$.

The concentration effect of SPADNS chelating reagent and the dye $\mathrm{RhB}$ on the quantification of $\mathrm{Cd}(\mathrm{II})$ were subsequently studied and the results are presented in Figures 3 and 4, respectively. With these results, a SPADNS concentration of $1 \times 10^{-8} \mathrm{~mol} \cdot \mathrm{L}^{-1}$ and $\mathrm{RhB}$ of $2.5 \times$ $10^{-8} \mathrm{~mol} \cdot \mathrm{L}^{-1}$ were chosen as optimal for following assays.

\section{Analytical Parameters}

\subsection{Calibration Curve}

Calibration curve for different concentration levels of $\mathrm{Cd}(\mathrm{II})$ $0.192-1.2 \times 10^{4} \mu \mathrm{g} \cdot \mathrm{L}^{-1}$ was attempted applying the developed methodology. Table 1 summarizes the main characteristics of the calibration plot and optimized experimental conditions, which sustain the proposed procedure for quantification of $\mathrm{Cd}(\mathrm{II})$ traces.

The limits of detection (LOD) and quantification (LOQ) were calculated in accordance to the formulas given by the official compendia methods [16], using the relation $k(\mathrm{SD}) / m$ where $k=3$ for LOD and 10 for LOQ. SD represents the standard deviation from 15 replicate blank responses and $m$ is the slope of the calibration curve.

\subsection{Interferences Study}

The effect of foreign ions on the recovery of Cd(II) was tested. Different amounts of common cations in samples were added to the test solution containing $1.26 \mu \mathrm{g} \cdot \mathrm{L}^{-1}$ of $\mathrm{Cd}(\mathrm{II})$ and the developed procedure was applied. An ion was considered as interferent, when it caused a variation in the fluorescent signal of the sample greater than $\pm 5 \%$. The tolerance limits of various foreign ions are given in Table 2. These results demonstrate that large excess amounts of some common cations and anions do not interfere on the determination of trace level of $\mathrm{Cd}(\mathrm{II})$.

\section{Applications}

In order to study the usefulness of the proposed methodology, it was applied to the determination of $\mathrm{Cd}$ (II) in filter samples of ten different cigarette blends, which had been smoked by smoker subjects and automatically smoked. Additionally, in order to establish the contribution of filter materials on $\mathrm{Cd}(\mathrm{II})$ contents, unsmoked filters were also analyzed.

Filters were treated with different leachating solutions. An ideal leachating solution must fulfill with two essential conditions:

- To leach selectively the $\mathrm{Cd}(\mathrm{II})$ analyte.

- To show maximum fluorescent emission of ternary association Cd(II)-SPADNS-RhB.

With this objective, buffers TRIS ( $\mathrm{pH} 4.5,6.0$ and 7.0) and acetic/acetate $(\mathrm{pH} 4.0,5.0$ and 6.0) were assayed. Buffer acetic/acetate $\mathrm{pH} 4.0$ were selected as optimal, fulfilled with mentioned requirements.

Other optimized variable was the contact time of filters with leachating solutions. Experiences were carried out varying contact time from $30 \mathrm{~s}$ to $10 \mathrm{~min}$. The best results respect to sensitivity and selectivity were obtained for $1 \mathrm{~min}$ of contact time. For minor contact times, poor repeatability was obtained. For superior contact times, 


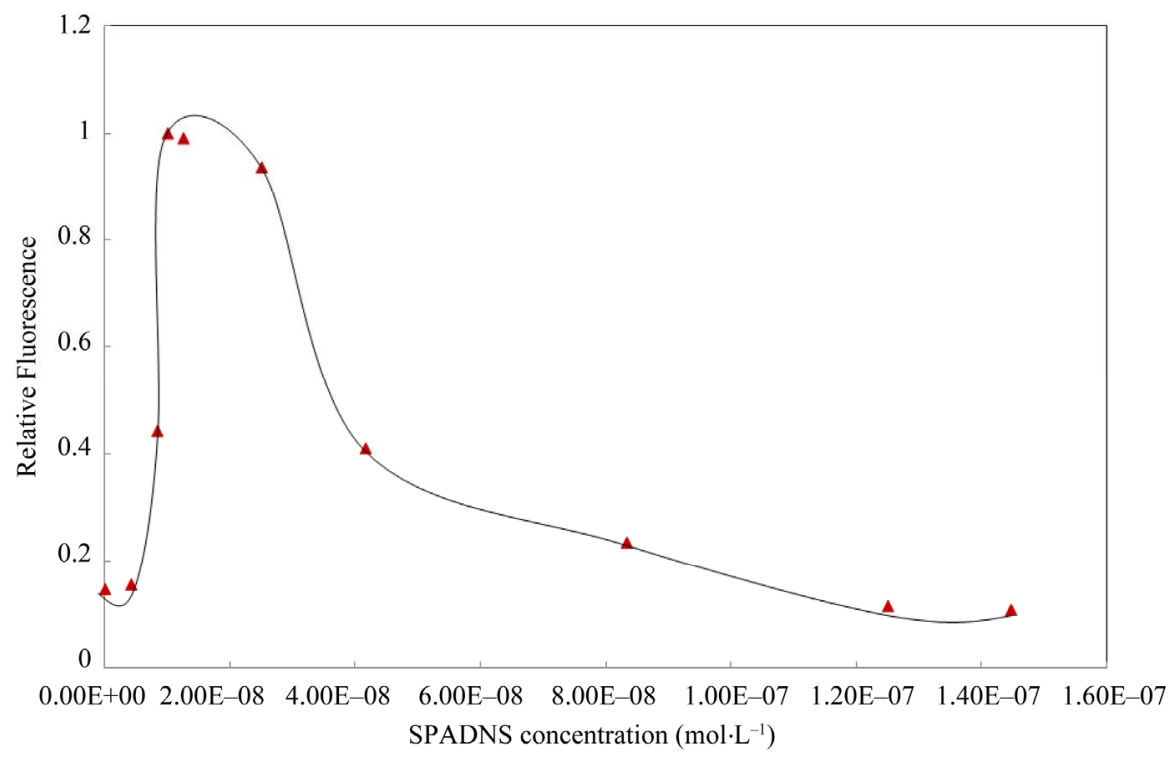

Figure 3. Effect of SPADNS concentration on the determination of cadmium. Conditions: $1.26 \mu \mathrm{g} \cdot \mathrm{L}^{-1} \mathrm{Cd}(\mathrm{II}), 2.5 \times 10^{-8}$ $\mathrm{mol} \cdot \mathrm{L}^{-1} \mathrm{RhB}$, pH 5.8 buffer acetic/acetate. Other experimental conditions are described under procedures.

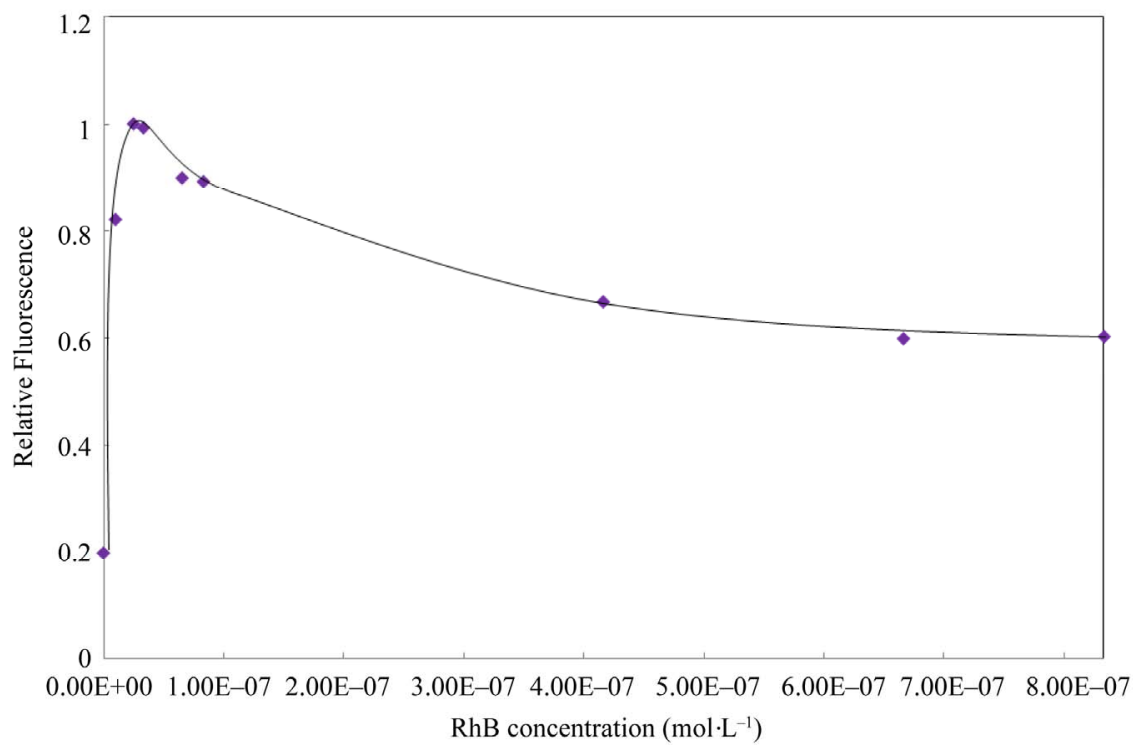

Figure 4. Effect of $\mathrm{RhB}$ concentration on the determination of cadmium Conditions: $1.26 \mu \mathrm{g} \cdot \mathrm{L}^{-1} \mathrm{Cd}(\mathrm{II}), 1 \times 10^{-8} \mathrm{~mol} \cdot \mathrm{L}^{-1}$ SPADNS, pH 5.8 buffer acetic/acetate. Other experimental conditions are described under procedures.

Table 1. Experimental conditions and analytical parameters for cadmium determination.

\begin{tabular}{ccc}
\hline Parameters & Studied Range & Optimal conditions \\
\hline pH & $4.0-6.7$ & 5.8 \\
Buffer acetic/acetate & $4 \times 10^{-4}-0.5 \mathrm{~mol} \cdot \mathrm{L}^{-1}$ & $1.2 \times 10^{-4} \mathrm{~mol} \cdot \mathrm{L}^{-1}$ \\
SPADNS concentration & $1 \times 10^{-9}-1.5 \times 10^{-7} \mathrm{~mol} \mathrm{~L}-1$ & $1 \times 10^{-8} \mathrm{~mol} \cdot \mathrm{L}^{-1}$ \\
RhB concentration & $1 \times 10^{-9}-8 \times 10^{-7} \mathrm{~mol} \cdot \mathrm{L}^{-1}$ & $2.5 \times 10^{-8} \mathrm{~mol} \cdot \mathrm{L}^{-1}$ \\
LOD & - & $0.057 \mu \mathrm{g} \cdot \mathrm{L}^{-1}$ \\
LOQ & - & $0.192 \mu \mathrm{g} \cdot \mathrm{L}^{-1}$ \\
LOL & - & $0.192-1.2610^{4} \mu \mathrm{g} \cdot \mathrm{L}^{-1}$ \\
Calibration sensitivity & - & $7 \times 10^{8} \mathrm{~L} \cdot \mu \mathrm{g}$ \\
$\mathrm{r}^{2}$ & - & 0.999
\end{tabular}


Table 2. Study of tolerance.

\begin{tabular}{ccc}
\hline Foreign ion & Fluorescent emission & $\mathrm{CV}$ \\
\hline $\mathrm{CO}_{3}^{-}$ & 127.651 & 0.03 \\
$\mathrm{SO}_{4}^{2-}$ & 128.980 & 0.02 \\
$\mathrm{NO}_{3}^{-}$ & 126.355 & 0.04 \\
$\mathrm{Cl}^{-}$ & 128.098 & 0.01 \\
$\mathrm{~F}^{-}$ & 132.432 & 0.02 \\
$\mathrm{~K}^{1+}$ & 131.331 & 0.01 \\
$\mathrm{Na}^{1+}$ & 128.188 & 0.05 \\
$\mathrm{Zn}^{2+}$ & 131.221 & 0.07 \\
$\mathrm{Fe}^{3+}$ & 127.537 & 0.01 \\
$\mathrm{Ca}^{2+}$ & 126.877 & 0.10 \\
$\mathrm{~Pb}^{2+}$ & 132.509 & 0.05 \\
$\mathrm{Cd}^{2+}$ & 130.278 & 0.04 \\
$\mathrm{Mg}^{2+}$ & 126.077 & 0.07 \\
$\mathrm{Mn}^{2+}$ & 127.344 & 0.12 \\
$\mathrm{Cu}^{2+}$ & 126.321 & 0.09 \\
$\mathrm{Co}^{2+}$ & 127.654 & 0.03 \\
\hline
\end{tabular}

(") $1000 / 1$ interferent/Cd(II) ratio.

spectral interferences were observed.

The accuracy of the methodology was evaluated using the standard addition method. Adequate volumes of leachate solutions were spiked with increasing amounts of Cd(II) $\left(0.192-15.0 \mu \mathrm{g} \cdot \mathrm{L}^{-1}\right)$. The reproducibility of the method was evaluated repeating the proposed methodology, four times for each sample. The recoveries of Cd(II) in each type of sample based on the average of replicate measurements are illustrated in Tables 3-5; the obtained results showed that the proposed method was appropriate for determination of $\mathrm{Cd}(\mathrm{II})$ in studied filter cigarettes samples.

Taking into account these results and considering permitted maxima limits for $\mathrm{Cd}(\mathrm{II})$ concentration for drinking water by EPA (Environmental Protection Agency, 5 $\mu \mathrm{g} \cdot \mathrm{L}^{-1}$ ) and WHO (World Health Organization, $3 \mu \mathrm{g} \cdot \mathrm{L}^{-1}$ ) [17], it can be concluded that filters represent a severe problem of environmental pollution.

Experiments realized on unsmoked cigarettes filters showed Cd(II) levels of order of $1 \mu \mathrm{g} \cdot \mathrm{L}^{-1}$, contributing moderately to found total $\mathrm{Cd}(\mathrm{II})$. Respect to results of automatically smoked cigarettes, $9 / 10 \mathrm{Cd}$ (II) contents of studied filters leachates were superior to WHO established limit (Figure 5) and 2/10 exceed the EPA established limit. Moreover, for smoked cigarettes by smoker subjects, $10 / 10 \mathrm{Cd}$ (II) contents of filters leachates were superior to WHO established limit and 7/10 exceed the EPA established limit.

\section{Conclusion}

Atomic spectrocopies represent the most important techniques for metal trace analysis, but they require special-

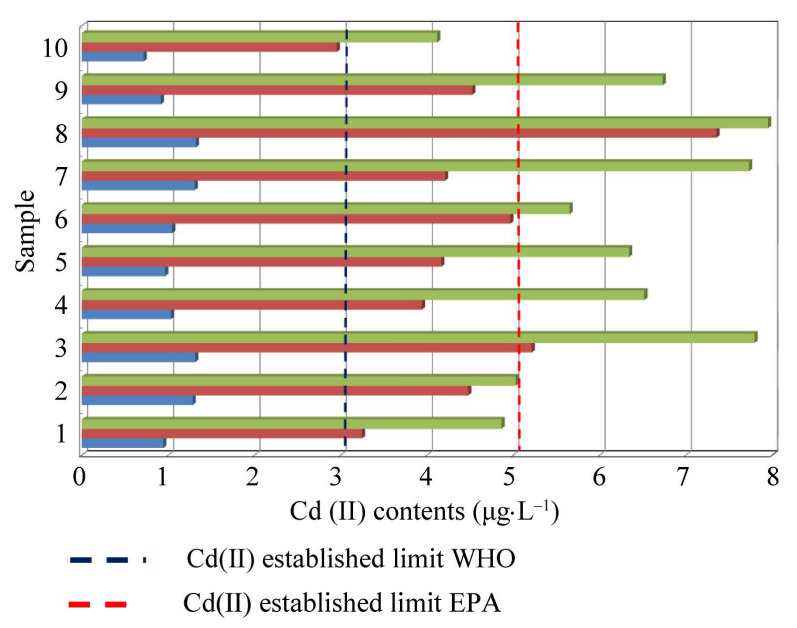

Figure 5. Cadmium contents in studied filters leachates respect to established limits for EPA and WHO in drink water.

Table 3. Recuperation study (filters of unsmoked cigarettes).

\begin{tabular}{|c|c|c|c|c|}
\hline Sample & $\begin{array}{l}\text { Cd(II) added } \\
\left(\mu \mathrm{g} \cdot \mathrm{L}^{-1}\right)\end{array}$ & $\begin{array}{l}\text { Cd(II) found } \\
\pm \mathrm{CV}\left(\mu \mathrm{g} \cdot \mathrm{L}^{-1}\right)\end{array}$ & $\begin{array}{l}\text { Recovery } \\
(\%, n=5)\end{array}$ & $\begin{array}{l}\mathrm{Cd}(\mathrm{II}) \\
\mu \mathrm{g} \cdot \mathrm{g}^{-1}\end{array}$ \\
\hline \multirow{3}{*}{$1^{\mathrm{c}}$} & - & $0.945 \pm 0.04$ & - & \multirow{3}{*}{7.4} \\
\hline & 1.26 & $2.212 \pm 0.04$ & 100.55 & \\
\hline & 3.16 & $4.097 \pm 0.04$ & 99.75 & \\
\hline \multirow{3}{*}{$2^{\mathrm{b}}$} & - & $1.284 \pm 0.03$ & - & \multirow{3}{*}{10.1} \\
\hline & 3.0 & $4.288 \pm 0.08$ & 100.13 & \\
\hline & 4.5 & $5.749 \pm 0.07$ & 99.22 & \\
\hline \multirow{3}{*}{$3^{c}$} & - & $1.314 \pm 0.05$ & - & \multirow{3}{*}{10.3} \\
\hline & 2.0 & $3.342 \pm 0.03$ & 101.40 & \\
\hline & 3.0 & $4.277 \pm 0.01$ & 98.77 & \\
\hline \multirow{3}{*}{$4^{b}$} & - & $1.033 \pm 0.02$ & - & \multirow{3}{*}{8.1} \\
\hline & 2.0 & $3.056 \pm 0.05$ & 101.15 & \\
\hline & 3.16 & $4.201 \pm 0.04$ & 100.25 & \\
\hline \multirow{3}{*}{$5^{\mathrm{d}}$} & - & $0.966 \pm 0.07$ & - & \multirow{3}{*}{7.6} \\
\hline & 1.26 & $2.211 \pm 0.08$ & 98.80 & \\
\hline & 3.16 & $4.137 \pm 0.07$ & 100.35 & \\
\hline \multirow{3}{*}{$6^{\mathrm{d}}$} & - & $1.046 \pm 0.01$ & - & \multirow{3}{*}{8.2} \\
\hline & 1.26 & $2.278 \pm 0.04$ & 97.77 & \\
\hline & 2.0 & $3.054 \pm 0.04$ & 100.40 & \\
\hline \multirow{3}{*}{$7^{\mathrm{c}}$} & - & $1.308 \pm 0.05$ & - & \multirow{3}{*}{10.2} \\
\hline & 1.26 & $2.566 \pm 0.04$ & 99.84 & \\
\hline & 2.0 & $3.314 \pm 0.04$ & 100.30 & \\
\hline \multirow{3}{*}{$8^{c}$} & - & $1.321 \pm 0.02$ & - & \multirow{3}{*}{10.4} \\
\hline & 1.26 & $2.594 \pm 0.04$ & 101.03 & \\
\hline & 2.0 & $3.331 \pm 0.04$ & 100.50 & \\
\hline \multirow{3}{*}{$9^{\mathrm{d}}$} & - & $0.915 \pm 0.03$ & - & \multirow{3}{*}{7.2} \\
\hline & 1.26 & $2.187 \pm 0.04$ & 100.95 & \\
\hline & 2.0 & $2.896 \pm 0.04$ & 99.05 & \\
\hline \multirow{3}{*}{$10^{\mathrm{a}}$} & - & $0.717 \pm 0.03$ & - & \multirow{3}{*}{5.6} \\
\hline & 0.63 & $1.348 \pm 0.02$ & 100.16 & \\
\hline & 1.26 & $2.002 \pm 0.03$ & 101.98 & \\
\hline
\end{tabular}

Tobaccolist: Samples; 1 - 6 and 10: Massalin Particulares; 7 - 9: Nobleza Piccardo. Filter ventilations: ${ }^{\mathrm{a}}$ Four lines ( 25 holder each one); ${ }^{\mathrm{b}}$ One line (6 holder); ${ }^{\mathrm{c}}$ Two lines (11 holder each one); ${ }^{\mathrm{d}}$ Two lines ( 25 holder each one). 
Table 4. Recuperation study (filters of automatically smoked cigarettes).

\begin{tabular}{|c|c|c|c|c|}
\hline Sample & $\begin{array}{l}\text { Cd(II) added } \\
\left(\mu \mathrm{g} \cdot \mathrm{L}^{-1}\right)\end{array}$ & $\begin{array}{l}\mathrm{Cd}(\mathrm{II}) \text { found } \\
\pm \mathrm{CV}\left(\mu \mathrm{g} \cdot \mathrm{L}^{-1}\right)\end{array}$ & $\begin{array}{l}\text { Recovery } \\
(\%, n=5)\end{array}$ & $\begin{array}{r}\mathrm{Cd}(\mathrm{II}) \\
\mathrm{g} \cdot \mathrm{g}^{-1}\end{array}$ \\
\hline \multirow{3}{*}{$1^{\mathrm{c}}$} & - & $3.248 \pm 0.02$ & - & \multirow{3}{*}{27.0} \\
\hline & 1.26 & $4.512 \pm 0.04$ & 100.12 & \\
\hline & 3.16 & $6.413 \pm 0.04$ & 100.15 & \\
\hline \multirow{3}{*}{$2^{\mathrm{b}}$} & - & $4.478 \pm 0.07$ & - & \multirow{3}{*}{29.5} \\
\hline & 3.0 & $5.730 \pm 0.08$ & 99.8 & \\
\hline & 4.5 & $7.648 \pm 0.07$ & 100.2 & \\
\hline \multirow{3}{*}{$3^{c}$} & - & $5.215 \pm 0.05$ & - & \multirow{3}{*}{36.8} \\
\hline & 2.0 & $6.470 \pm 0.03$ & 98.91 & \\
\hline & 3.0 & $8.364 \pm 0.01$ & 100.47 & \\
\hline \multirow{3}{*}{$4^{b}$} & - & $3.942 \pm 0.03$ & - & \multirow{3}{*}{30.9} \\
\hline & 2.0 & $6.003 \pm 0.05$ & 103.05 & \\
\hline & 3.16 & $7.047 \pm 0.04$ & 98.26 & \\
\hline \multirow{3}{*}{$5^{\mathrm{d}}$} & - & $4.167 \pm 0.04$ & - & \multirow{3}{*}{31.8} \\
\hline & 1.26 & $5.463 \pm 0.08$ & 102.85 & \\
\hline & 3.16 & $7.301 \pm 0.07$ & 99.17 & \\
\hline \multirow{3}{*}{$6^{\mathrm{d}}$} & - & $4.932 \pm 0.02$ & - & \multirow{3}{*}{32.1} \\
\hline & 2.0 & $6.947 \pm 0.03$ & 100.75 & \\
\hline & 3.16 & $8.113 \pm 0.08$ & 100.66 & \\
\hline \multirow{3}{*}{$7^{\mathrm{c}}$} & - & $4.211 \pm 0.07$ & - & \multirow{3}{*}{39.6} \\
\hline & 1.26 & $5.467 \pm 0.09$ & 99.70 & \\
\hline & 3.16 & $7.387 \pm 0.02$ & 100.50 & \\
\hline \multirow{3}{*}{$8^{c}$} & - & $7.355 \pm 0.07$ & - & \multirow{3}{*}{40.5} \\
\hline & 1.26 & $8.603 \pm 0.08$ & 99.05 & \\
\hline & 3.16 & $10.527 \pm 0.09$ & 100.38 & \\
\hline \multirow{3}{*}{$9^{d}$} & - & $4.525 \pm 0.02$ & - & \multirow{3}{*}{34.5} \\
\hline & 1.26 & $5.763 \pm 0.05$ & 98.25 & \\
\hline & 2.0 & $6.489 \pm 0.05$ & 98.20 & \\
\hline \multirow{3}{*}{$10^{\mathrm{a}}$} & - & $2.957 \pm 0.01$ & - & \multirow{3}{*}{21.9} \\
\hline & 0.63 & $4.194 \pm 0.02$ & 98.17 & \\
\hline & 1.26 & $6.146 \pm 0.03$ & 100.92 & \\
\hline
\end{tabular}

Tobaccolist: Samples; 1 - 6 and 10: Massalin Particulares; 7 - 9: Nobleza Piccardo. Filter ventilations: ${ }^{\mathrm{a}}$ Four lines ( 25 holder each one); ${ }^{\mathrm{b}}$ One line (6 holder); ${ }^{\mathrm{c}}$ Two lines ( 11 holder each one); ${ }^{\mathrm{d}}$ Two lines ( 25 holder each one).
Table 5. Recuperation study (filters of cigarettes smoked by smoker subjects).

\begin{tabular}{|c|c|c|c|c|}
\hline Sample & $\begin{array}{l}\text { Cd(II) added } \\
\left(\mu \mathrm{g} \cdot \mathrm{L}^{-1}\right)\end{array}$ & $\begin{array}{l}\mathrm{Cd}(\mathrm{II}) \text { found } \\
\pm \mathrm{CV}\left(\mu \mathrm{g} \cdot \mathrm{L}^{-1}\right)\end{array}$ & $\begin{array}{l}\text { Recovery } \\
(\%, n=5)\end{array}$ & $\begin{array}{r}\mathrm{Cd}(\mathrm{II}) \\
\mathrm{g} \cdot \mathrm{g}^{-1}\end{array}$ \\
\hline \multirow{3}{*}{$1^{\mathrm{c}}$} & - & $4.864 \pm 0.08$ & - & \multirow{3}{*}{38.2} \\
\hline & 1.26 & $6.114 \pm 0.03$ & 100.14 & \\
\hline & 3.16 & $8.031 \pm 0.02$ & 98.66 & \\
\hline \multirow{3}{*}{$2^{\mathrm{b}}$} & - & $5.027 \pm 0.04$ & - & \multirow{3}{*}{41.7} \\
\hline & 1.26 & $6.279 \pm 0.03$ & 99.83 & \\
\hline & 3.16 & $8.195 \pm 0.02$ & 100.14 & \\
\hline \multirow{3}{*}{$3^{\mathrm{c}}$} & - & $7.798 \pm 0.02$ & - & \multirow{3}{*}{52.1} \\
\hline & 3.16 & $11.004 \pm 0.08$ & 101.45 & \\
\hline & 5.10 & $12.900 \pm 0.07$ & 100.05 & \\
\hline \multirow{3}{*}{$4^{\mathrm{b}}$} & - & $6.521 \pm 0.01$ & - & \multirow{3}{*}{43.7} \\
\hline & 3.16 & $9.694 \pm 0.09$ & 100.41 & \\
\hline & 5.10 & $11.712 \pm 0.04$ & 101.78 & \\
\hline \multirow{3}{*}{$5^{\mathrm{d}}$} & - & $6.344 \pm 0.06$ & - & \multirow{3}{*}{45.0} \\
\hline & 1.26 & $7.583 \pm 0.03$ & 98.33 & \\
\hline & 3.16 & $9.525 \pm 0.07$ & 100.66 & \\
\hline \multirow{3}{*}{$6^{\mathrm{d}}$} & - & $5.655 \pm 0.04$ & - & \multirow{3}{*}{45.4} \\
\hline & 1.26 & $6.919 \pm 0.03$ & 100.07 & \\
\hline & 3.16 & $8.808 \pm 0.01$ & 99.90 & \\
\hline \multirow{3}{*}{$7^{\mathrm{c}}$} & - & $7.733 \pm 0.05$ & - & \multirow{3}{*}{56.0} \\
\hline & 2.0 & $9.712 \pm 0.09$ & 98.95 & \\
\hline & 3.16 & $10.902 \pm 0.03$ & 100.28 & \\
\hline \multirow{3}{*}{$8^{\mathrm{c}}$} & - & $7.954 \pm 0.03$ & - & \multirow{3}{*}{57.3} \\
\hline & 1.26 & $9.906 \pm 0.05$ & 99.20 & \\
\hline & 3.16 & $11.127 \pm 0.06$ & 100.41 & \\
\hline \multirow{3}{*}{$9^{d}$} & - & $6.733 \pm 0.01$ & - & \multirow{3}{*}{48.8} \\
\hline & 1.26 & $8.012 \pm 0.07$ & 101.50 & \\
\hline & 2.0 & $8.703 \pm 0.03$ & 98.50 & \\
\hline \multirow{3}{*}{$10^{\mathrm{a}}$} & - & $4.119 \pm 0.05$ & - & \multirow{3}{*}{31.0} \\
\hline & 1.26 & $5.394 \pm 0.04$ & 101.19 & \\
\hline & 3.16 & $7.258 \pm 0.03$ & 99.33 & \\
\hline
\end{tabular}

Tobaccolist: Samples; 1 - 6 and 10: Massalin Particulares; 7 - 9: Nobleza Piccardo. Filter ventilations: ${ }^{\mathrm{a}}$ Four lines ( 25 holder each one); ${ }^{\mathrm{b}}$ One line (6 holder); ${ }^{\mathrm{c}}$ Two lines ( 11 holder each one); ${ }^{\mathrm{d}}$ Two lines ( 25 holder each one). 
ized and very expensive instruments. The development of new simple and rapid analytical methods for $\mathrm{Cd}(\mathrm{II})$ traces determination continues being an actual topic due to toxicological relevance of metal. The proposed method symbolizes a promising approach for $\mathrm{Cd}(\mathrm{II})$ monitoring with low operation cost, simplicity of instrumentation and non-polluting solvents. The method was validated with real samples with good tolerance to regular foreign cigarettes constituents. Results permit asseverate that filter cigarettes must be qualified as dangerous wastes. Smoking was found to increase notoriously the toxicity of cigarette filters. Control agencies and health agents must to establish precise mode for its end destiny.

\section{Acknowledgements}

Authors wish to thanks to Instituto de Química San Luis - Consejo Nacional de Investigaciones Científicas y Tecnológicas (INQUISAL-CONICET), National University of San Luis (Project 22/Q828) for the financial support.

\section{REFERENCES}

[1] M. Borgerding and H. Klus, "Analysis of Complex Mixtures-Cigarette Smoke," Experimental and Toxicologic Pathology, Vol. 57, No. S1, 2005, pp. 43-73. doi:10.1016/j.etp.2005.05.010

[2] M. Kleeman, J. Schauer and G. Cass, "Size and Composition Distribution of Fine Particulate Matter Emitted from Wood Burning, Meat Charbroiling, and Cigarettes," Environmental Science \& Technology, Vol. 33, No. 20, 1999, pp. 3516-3523. doi:10.1021/es981277q

[3] D. Hoffmann and I. Hoffmann, "The Changing Cigarette, 1950-1995," Journal of Toxicology and Environmental Health, Vol. 50, No. 4, 1997, pp. 307-364. doi:10.1080/009841097160393

[4] H. Bradford, "The Intractable Cigarette 'Filter Problem,," Tobacco Control, Vol. 20, No. S1, 2011, pp. i10-i16. doi:10.1136/tc.2010.040113

[5] A. Zipser, "Cigarette Industry Convalescing Filter Prescription Seems to Help: Cigarette Output Survives a Crisis," New York Times, Manhattan, 1954.

[6] E. Slaughter, R. Gersberg, K. Watanabe, J. Rudolph, C. Stransky and T. Novotny, "Toxicity of Cigarette Butts, and Their Chemical Components, to Marine and Freshwater Fish," Tobacco Control, Vol. 20, No. S1, 2011, pp. i25-i29. doi:10.1136/tc.2010.040170

[7] S. Satarug and M. Moore, "Adverse Health Effects of Chronic Exposure to Low-Level Cadmium in Foodstuffs and Cigarette Smoke," Environmental Health Perspectives, Vol. 112, No. 10, 2004, pp. 1099-1103.

doi: $10.1289 /$ ehp. 6751

[8] A. N. Anthemidis, G. A. Zachariadis, C. G. Farastelis and J. A. Stratis, "On-Line Liquid-Liquid Extraction System Using a New Phase Separator for Flame Atomic Absorption Spectrometric Determination of Ultra-Trace Cadmium in Natural Waters," Talanta, Vol. 62, No. 3, 2004 , pp. 437-443. doi:10.1016/j.talanta.2003.07.019

[9] L. M. Coelho and M. A. Z. Arruda, "Preconcentration Procedure Using Cloud Point Extraction in the Presence of Electrolyte for Cadmium Determination by Flame Atomic Absorption Spectrometry," Spectrochimica Acta Part $B$, Vol. 60 , No. 50, 2005, pp. 743-748. doi:10.1016/i.sab.2005.02.016

[10] K. L. Linge, "Trace Element Determination by ICP-AES and ICP-MS: Developments and Applications Reported During 2004 and 2005," Geostandards and Geoanalytical Research, Vol. 30, No. 3, 2007, pp. 157-174. doi:10.1111/j.1751-908X.2006.tb01058.x

[11] H. G. Seiler, A. Sigel and H. Sigel, "Handbook on Metals in Clinical and Analytical Chemistry," Mercel Dekker, New York, 1994.

[12] L. Lampugnani, C. Salvetti and D. L. Tsalev, "Hydride Generation Atomic Absorption Spectrometry with Different Flow Systems and In-Atomizer Trapping for Determination of Cadmium in Water and Urine Overview of Existing Data on Cadmium Vapour Generation and Evaluation of Critical Parameters," Talanta, Vol. 61, No. 5, 2003, pp. 683-698. doi:10.1016/S0039-9140(03)00324-2

[13] M. Talio, M. Luconi, A. Masi and L. Fernández, "Determination of Cadmium at Ultra-Trace Levels by CPE-Molecular Fluorescence Combined Methodology," Journal of Hazardous Materials, Vol. 170, No. 1, 2009, pp. 272277. doi:10.1016/j.jhazmat.2009.04.101

[14] M. Talio, M. Luconi, A. Masi and L. Fernández, "Cadmium Monitoring in Saliva and Urine as Indicator of Smoking Addiction," Science of the Total Environment, Vol. 408, No. 16, 2010, pp. 3125-3132. doi:10.1016/j.scitotenv.2010.03.052

[15] P. M. Jayaweera, T. Samjeewa and K. Tennakone, "Formation of Ion Associated Complexes between SPANDS and Rhodamine B: Antenna Effect and Enhancement of Photovoltaic Properties," Solar Energy Materials and Solar Cells, Vol. 91, No. 10, 2007, pp. 944-950. doi:10.1016/j.solmat.2007.02.014

[16] J. C. Miller and J. N. Miller, "Statistics for Analytical Chemistry," 4th Edition, Ellis-Howood, New York, 1994. p. 115.

[17] J. Moerman, "Analysis of Metals Leached from Smoked Cigarette Litter by ICP-OES," University of Tennessee, Knoxville, 2009. 